\section{Innovation in Small Businesses: towards an Owner-Centered Approach to Innovation}

\author{
Glessia Silva ${ }^{1}$ \\ Luiz Carlos Di Serio ${ }^{2}$
}

\begin{abstract}
Purpose - We aim to understand how small business owners develop innovations.

Theoretical framework - We adopt social cognitive theory to understand innovative activities in small businesses. We draw on Schumpeter's work to understand how owners may develop innovations and how an owner-centered approach to innovation should take form.
\end{abstract}

Design/methodology/approach - We conducted a multiple case study in small businesses from different traditional sectors. We conducted in-depth semi-structured interviews with the participants and we accessed data from social networks such as the Facebook and Instagram fan pages of the businesses.

Findings - The results explain what drives business owners towards innovation and what affects the innovation structure of their businesses. These results are expressed through the antecedents of innovation that emerged from the field and may help in explaining the differences between innovative small businesses and non-innovative small businesses.

Research Practical \& Social implications - We developed an approach designed for studying innovation within the context and reality of small businesses. In order to contribute to the development of innovations in forgotten businesses, we have listed some recommendations for supporting agencies, government bodies, and researchers alike.

Originality/value - Small business innovation is influenced by the owner's propensity to recognize and act on opportunities. Therefore, the owner can guide the innovation activity in a small business and this needs to be considered by researchers.

Keywords - Innovation. Model. Small Business. Owner.

1. Universidade Federal de Sergipe, Departamento de Administração, São Cristóvão, Brazil

2. Fundação Getulio Vargas, Departamento de Produção e Operações, São Paulo, Brazil

How to cite:

Silva, G., Di Serio, L. C. (2021). Innovation in the Small Business: Towards an Owner-Centered Innovation Approach. Revista Brasileira de Gestão de Negócios, 23(3), p.519-535.
Received on:

11/30/2019

Approved on:

02/05/2021

Responsible Editor:

Prof. Dr. José Liébana

\section{Evaluation process:}

Double Blind Review

\section{Reviewers:}

Nizar Alsharari; Catarina Nunes

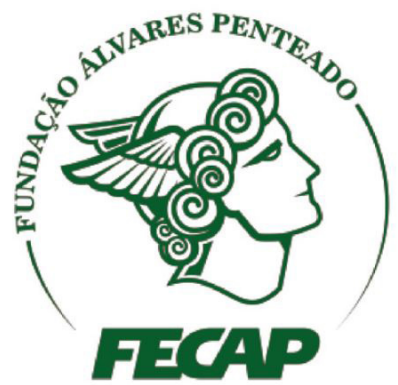

Revista Brasileira de Gestáo de Negócios

https://doi.org/10.7819/rbgn.v.23i3.4117 


\section{Introduction}

In a way, the innovation literature lacks knowledge on the elements that lead to innovations in small businesses (Ferreira, Fernandes, Alves, \& Raposo, 2015). Because a small enterprise develops activities and innovation outcomes which are fundamentally different from those found in big, high-technology enterprises (Forsman, 2011), framing small businesses within the traditional innovation model in a "one-size-fits-all" way might lead to misperceptions about the innovation performance of these businesses (Santamaría, Nieto, \& Barge-Gil, 2009).

Such models also use as their theoretical basis what the innovation literature understands as important for the development of innovations (Forsman, 2011). The point is that the field of innovation has a strong bias towards R\&D and big, high-technology businesses (Birkinshaw, Hamel, \& Mol, 2008; Damanpour, 2014; Ferreira et al., 2015; Garcia \& Calantone, 2002; Santamaría et al., 2009). Therefore, traditional innovation models - which are mostly based on that innovation context - fail to capture specific elements which are particular to small businesses, such as the manager/owner also being the main - if not the only - decision maker (De Jong \& Marsili, 2006; Silva, Dacorso, \& Montenegro, 2016; Verhees \& Meulenberg, 2004), or their more tacit innovation management (Brunswicker \& Ehrenmann, 2013; Fitjar, Gjelsvik, \& Rodríguez-Pose, 2013).

Moreover, while the advantages of small businesses are of a behavioral nature (Rothwell, 1989), most of the traditional innovation models are based on material and recursive attributes (Glover et al., 2016). Consequently, some important socio-cognitive aspects in the development of innovations in small businesses are generally ignored by the traditional innovation models (Cooper, Peake, \& Watson, 2016; Taneja, Pryor, \& Hayek, 2016; Zaridis \& Mousiolis, 2014).

Ironically, even the literature on innovation in small businesses shows some degree of preference for small, high-technology firms (Storey, 2014). However, the majority of small businesses belong to traditional sectors, they are low-technology, and they do not use $\mathrm{R} \& \mathrm{D}$ activities in their innovation processes (McGuirk, Lenihan, \& Hart, 2015; Plotnikova, Romero, \& MartínezRomán, 2016; Romero \& Martínez-Román, 2012; Zaridis \& Mousiolis, 2014). This situation is worrying, as small businesses make up the basis of any country's economic and social development (Patanakul \& Pinto,
2014), and even so they are underresearched in the field of innovation (McGuirk et al., 2015; Plotnikova, et al., 2016; Romero \& Martínez-Román, 2012; Zaridis \& Mousiolis, 2014) because they are seen as less "glamorous" firms (Storey, 2014).

In order to addreess this research gap, the objective of this article is to understand how small business owners develop innovations. These enterprises, which together make up what from now on we will call "forgotten businesses," are studied using a multiple case study research design focusing on the traditional, lowtechnology sectors, which are not $R \& D$ intensive in their innovation proccesses. We coined and decided to use the term forgotten businesses to refer to the less glamorous small businesses from traditional, less technology-intensive sectors, which paradoxically make up the bulk of the economy in most countries, but have nonetheless been overlooked in the innovation literature, policymaking, and development models.

Therefore, we conducted a study on small businesses and their owners. At first based on the literature and the theoretical lenses that guide much of the research on entrepreneurship, we then proceeded to inductively frame our cases. The narrative accounts of the interviewees comprised the corpus of our raw data, which were later coded and analyzed in light of the exiting literature on small business characteristics and innovation.

We adopt a socio-cognitive perspective and make a case for the importance of the manager/owner's role in generating innovation. It is important to consider the owner as the central element of the innovation proccess because he/she is the person in charge of the decision making in the small business (Whittaker, Fath, \& Fiedler, 2016). It is impossible to discuss innovation in this context without putting an emphasis on the owner (Moraes et al., 2014). We thus recognize that recursive theories are insufficient to explain innovation in small bussinesses, and propose the socio-cognitive perspective as a theoretical and analytical lens to study the phenomenon, as it allows the researcher to explore the owner's perceptions and intentions (Cooper et al., 2016; Huarng \& Ribeiro-Soriano, 2014; Liñán, Santos, \& Fernández, 2011; Silva et al., 2016).

We also adopt the literature on innovation, small businesses, and entrepreneurship as our substantive domain. This is because the innovation literature is insufficient to explain innovation in small businesses (Berends, Jelinek, Reymen, \& Stultiëns, 2014; De Jong \& Marsili, 2006; Glover et al., 2016) and because the focus on the owner calls 
for us to consider the field of entrepreneurship. We then follow Garcia and Calantone's (2002) recommendations and adopt as our unit of analysis the "new to the business" and "new to the customer/market" perspectives. Likewise, this study uses Schumpeter's (1939) concept of innovation.

This article is developed as follows. We discuss tradional innovation models and why these may not be appropriate as frameworks for studying small businesses. We thus consider an owner-centered approach to small businesses and discuss the three propositions that guided our field work. Section 4 presents the methodology and the steps taken when conducting the field work. Section 5 presents the results and discussion of the multiple case study in light of the existing literature. Finally, section 6 concludes the article with recommendations for governments, supporting agencies, and researchers of small businesses.

\section{Looking beyond the Traditional Innovation Models}

Traditional innovation models are insufficient to explain innovation in small businesses, because most of them (e.g. Avlonitis, Kouremenos, \& Tzokas, 1994; Crossan \& Apaydin, 2010; Lawson \& Samsom, 2001; Read, 2000; Smith M., Busi, Ball, \& Van Der Meer, 2008; Tang, 1998; Van de Panne, Van Beers \& Kleinknecht, 2003) are based on recursive theories which put more emphasis on the technological, financial, and recursive aspects of the innovation process (Glover, Champion, Daniels, \& Boocock, 2016).

By "insufficient" we refer to the traditional models' adherence problem when it comes to the underresearched forgotten businesses in the three empirical research domains - substantive, conceptual, and methodological - that underlie organizational studies and the competing paradigms of qualitative research (Brinberg \& McGrath, 1988).

If we look at the innovation factors that compose these models, we will notice that they prioritize the material and organizational structure in the development of innovation. Such models also derive their substantive, theoretical, and methodological domains from a strong emphasis on research and development and big, hightechnology businesses (Birkinshaw et al., 2008; Damanpour, 2014; Forsman, 2011; Santamaría et al., 2009). Therefore, traditional innovation models - which are mostly based on that innovation context and recursive theories related to "big businesses" - fail to capture specific elements which are particular to forgotten businesses, such as the owner being the main - if not the only - decision maker (De Jong \& Marsili, 2006; Martínez-Román \& Romero, 2017; Verhees \& Meulenberg, 2004), or their more tacit innovation management (Brunswicker \& Ehrenmann, 2013).

Firstly, the recursive theories assume and argue that a firm must acquire and control resources to achieve a sustained competitive advantage (Glover et al., 2016). However, even though they have contributed considerably to explaining the competitiveness of organizations, their focus on the firm as a "bundle of resources" has been criticized as reductionist, given the complexity of businesses (Kraaijenbrink, Spender, \& Groen, 2010). This has led to the innovation models being developed based on mistaken assumptions about innovation activities in businesses lacking a resource-based advantage - skills, experience, limited financial and material resources, organizational and marketing capabilities - as is the case of small enterprises (Glover et al., 2016). Therefore, resource-driven innovation models may lead to the false perception that small businesses are less innovative or not innovative at all, when in fact they fundamentally innovate by different means (Forsman, 2011; Glover et al., 2016).

Secondly, regardless of the organizational context, the strong emphasis on technological resources in the generation of innovations has been questioned (Birkinshaw et al., 2008; Ferreira et al., 2015), since a great deal of the activities that lead to innovation do not necessarily depend on technology and R\&D activities (Damanpour, 2014). This is particularly important for understanding innovation activities in small enterprises, because these businesses generally do not use technological attributes to innovate (Cooper et al., 2016; Forsman, 2011; Hotho \& Champion 2011; McGuirk et al., 2015).

Thirdly, the traditional innovation models advocate for a formal innovation structure, as a result of the linear innovation model (Santamaría et al., 2009). The big question is that small enterprises usually have no formal innovation process (De Jong \& Marsili, 2006; Forsman, 2011). They use informal innovation activities that blend into the firm's day-to-day activities, so that the boundary between conventional and innovation activities or routines is not clear (Forsman, 2011).

We argue that this makes it difficult to map the specific elements that drive innovation in forgotten businesses, and it has led researchers to indiscriminately 
use elements of big, high-technology, and R\&D-driven enterprises as taken-for-granted elements pertaining to each and every business. Here we neither oppose the traditional innovation models nor argue that they should be disregarded, but rather that studying innovation in forgotten businesses demands new approaches that consider the specific characteristics of said enterprises, given that the innovation activity of small and big companies is the product of different technological, economic, political, and competitive environments (Martínez-Román \& Romero, 2017).

\section{Antecedents of Innnovation in Small Businesses}

Based on Bandura's (1986) Social Cognitive Theory and Schumpeter's (1939) Theory of Economic Development (1939), we develop three propositions regarding the antecedents of innovation in small, forgotten businesses. Social Cognitive Theory understands that individuals engage in learning processes and that these processes relate to the environment (Bandura, 1986). Bandura's Triadic Reciprocality Model (Figure 1) assumes that human learning is determined by the reciprocity between: (1) personal factors (cognitive abilities, physical characteristics, personality, and beliefs), (2) environmental factors (physical environment, family, friends, and other social influences), and (3) behavioral factors (motor responses, social interactions, and language).

Bandura's model also explains cognition in the organizational context and the process of organizational learning and change (Higgins, 2000). Thus, in the sociocognitive view of organizations, what is an individual phenomenon and what is an organizational phenomenon are often confused (Gioia \& Sims, 1986), given that both are part of and influence the structures and processes that make up organizations. Because organizational objectives and the owner's motivations are intertwined and relate to cognitive factors (Verhees \& Meulenberg, 2004), the social cognitive theory may work as an important analytical lens for innovative activities in small businesses, revealing concepts and nuances that recursive theoretical lenses may fail to capture.

Indeed, the Schumpeterian Theory of Economic Development is responsible for the seminal concept of innovation and for associating innovation with economic development (Schumpeter, 1939). Therefore, we draw on Schumpeter's work to return to the core concept of innovation and use it as an analytical lens to examine how owners may develop innovations, as well as how such an owner-centered approach to innovation should take form.

The discussion on what specific elements influence small business innovation activities is far from being closed (Hotho \& Champion 2011), but there is a consensus in the literature on the manager's influence on success and innovation development in small enterprises (Cooper et al., 2016; Martínez-Román \& Romero, 2017; Romero \& Martínez-Román, 2012). Small business innovation is influenced by the owner's propensity to recognize and act on opportunities (Barreto, Nassif, \& Maria, 2014; Cooper et al., 2016). He/she identifies an opportunity and develops it through innovation (Barreto et al., 2014; Ucbasaran, Westhead, \& Wright, 2008). As a result, we argue that the research paradigm on innovation in small businesses must necessarily be owner-centered because, as we have discussed previously, it is not possible to analyze innovation in small businesses without analyzing the owner's behavior and the intertwined and unique relationship he/

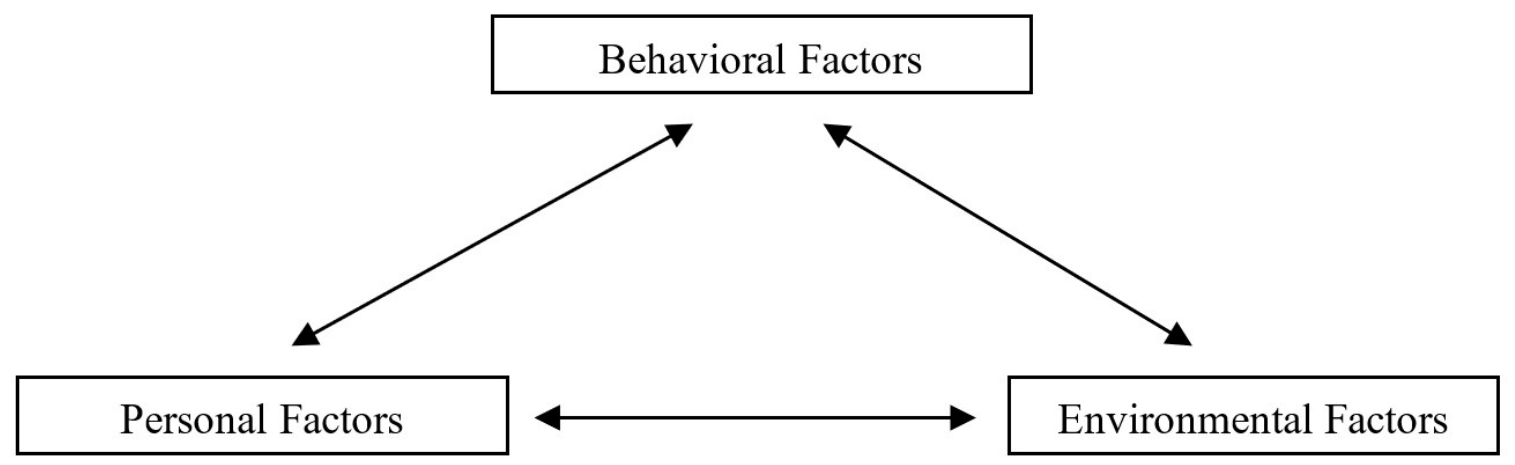

Figure 1. Triadic Reciprocality Model

Note. Source: Adapted from the "Triadic reciprocality model” from A. Bandura, 1986. 
she has with his/her business, both as an entrepreneur and manager as well as a worker (Moraes et al., 2014; Plotnikova et al., 2016).

Accordingly, this characteristic forces us to consider that innovation in small businesses is fundamentally different from in big businesses (Forsman, 2011). The experiences and personal capabilities of a practical individual may influence the performance of an innovator (Forsman, 2011). Likewise, small business owners are individuals who demonstrate a natural passion to create new things, which may also be an advantage in terms of innovation development (Taneja et al., 2016). Therefore, it is necessary to understand the antecedents of innovation in small businesses (Cooper et al., 2016; Freel, 2005). We argue that these antecedents are owner-centered, namely: (1) personal characteristics of the owner; (2) characteristics of the enterprise; and (3) the owner's will and ability to innovate.

\section{Proposition I: Innovation in small businesses depends upon the personal characteristics of the owner.}

Unlike in big enterprises, in which the organizational structure and presence of different actors put into place and promote innovation capabilities, in small enterprises decision making is one of the owner's roles, so small enterprise innovation performance is dependent on the owner's ability to gear decisions towards innovation (Danosh, Oteng, \& Frimpong, 2017; Hosseini \& Narayanan, 2014; Olughor, 2015). Nevertheless, most of the studies on innovation in small businesses focus on structure and not on the owner's characteristics, which in turn creates a distortion in our understanding on how innovation takes place in small enterprises, as well as which owner characteristics might contribute to innovation in such organizations (Daneji, Shavarebi, \& Yap, 2019).

The personal characteristics of the owner form a set of attributes that may favor or hinder innovation (Ilouga, Mouloungni, \& Sahut, 2014; McGuirk et al., 2015; Plotnikova et al., 2016). Such characteristics help explain what makes the owner "see beyond" (Carland, Carland, \& Stewart, 2015). Verhees and Meulenberg (2004) argue that innovation in small businesses depends on the owner's mastery of a specific area, so if he/she is a farmer the innovation will depend on the owner's knowledge of the farm business, for example.
Among the personal characteristics of small business owners mentioned in the literature that may favor or hinder innovation, we can mention the following: (a) educational level; (b) training in business management; (c) personal trajectory; (d) motivation; (e) business experience; (f) leadership; (g) willingness to change; and (h) wellbeing (Baron \& Tang, 2011; Dunne, Aaron, McDowell, Urban, \& Geho, 2016; Plotnikova et al., 2016; Romero \& Martínez-Román, 2012).

\section{Proposition 2: Innovation in small businesses depends upon the characteristics of the enterprise and these are affected by the owner's own characteristics.}

The characteristics of the enterprise are also determined by the owner (Plotnikova et al., 2016; Romero \& Martínez-Román, 2012) and affect the likelihood of the small business innovating (Plotnikova et al., 2016; Romero \& Martínez-Román, 2012; Taneja et al., 2016; Verhees \& Meulenberg, 2004; Zaridis \& Mousiolis, 2014). The many roles performed by the owner (Aminu \& Shariff, 2015), as well as his/her likeliness of adopting and/or generating an innovation (Hosseini \& Narayanan, 2014), direct the innovation activities developed by such businesses (Antonioli \& Della Toree, 2015; Blanchard, 2017). In this sense, the characteristics of a small enterprise and its innovation efforts are a reflection of the management attributes and personal characteristics of the owner (Farace \& Mazzotta, 2015), and the innovation efforts involve practices which the owner is able to control (Magadley \& Birdi, 2012).

While the characteristics of the enterprise are generally centered on the structure in big businesses, in small, forgotten businesses they are instead centered on the owner's behavior (Martínez-Román \& Romero, 2017; Rothwell, 1989). This leads to a set of considerably different attributes (Forsman, 2011).

Among the characteristics of enterprises that may favor or hinder innovation, we should list the following: (a) money reserved for innovation; (b) time dedicated to innovation; (c) existence of an innovation plan; (d) process optimization; (e) innovation culture; (f) institutional support; (g) cooperation; (h) internal flexibility; (i) training programs (De Jong \& Marsili, 2006; Galende \& de la Fuente, 2003; Plotnikova et al., 2016; Romero \& Martínez-Román, 2012; Santamaría et al., 
2009; Taneja et al., 2016; Verhees \& Meulenberg, 2004; Zaridis \& Mousiolis, 2014).

\section{Proposition 3: Innovation in small businesses depends upon the owner's will and ability to innovate and these are affected by the owner's personal characteristics and those of the enterprise.}

While ability is necessary for innovation, will is the intention to pursue innovation (De Massis, Kotlar, Chua, \& Chrisman, 2014, Dunne et al., 2016). A big business may create a structure that is favorable to innovation even against the will of some of its managers or stakeholders (Uzkurt, Kumar, Kimzan, \& Eminoglu, 2013). Conversely, the owner of a small business concentrates all of the decision-making power in himself/herself (De Jong \& Marsili, 2006; Martínez-Román \& Romero, 2017; Verhees \& Meulenberg, 2004). Surprisingly, if there is a will to innovate but a lack of skills, the owner may try and develop new skills to thus allow him/her to innovate (De Massis et al., 2014; Dunne et al., 2016), but not the other way around. It does not matter if the owner has the ability to innovate, because if he/she does not want to innovate then the business will not do so.

Small, forgotten businesses can potentially generate any kind of innovation (Martínez-Román \& Romero, 2017). But when it comes to business intention, small enterprise owners may "suffer" from unwillingness to risk transforming their will into action, or they may be more geared towards survival as a result of their personal characteristics (Ilouga et al., 2014). More than in bigger businesses, much of the innovation in small businesses originates from tacit knowledge, from the "learning by doing" of day-to-day activities and routines, so it depends on the humans who are part of said enterprises and their social environment (Brunswicker \& Ehrenmann, 2013; Freel, 2005).

\section{Methodology}

Given the open, qualitative nature of our research question - how do small business owners develop innovations? - we chose an inductive multiple case study as our research method (Eisenhardt, 1989; Yin, 2017). We sought to understand the personal and managerial characteristics of the owners in relation to the innovation process in their small businesses. We sought to carry out an analysis that made sense within each case and that was theoretically sound and related to the existing literature (Eisenhardt, 1989; Langley \& Abdallah, 2011).

The field study was conducted in a capital city in northeastern Brazil. We carried out five case studies using the following criteria: (1) the enterprise had to be a small business; (2) it had to belong to a traditional sector; (3) it had to be a low-technology business; (4) it could not use R\&D in its innovation processes; (5) it had to engage in an economic activity that could be carried out in any locality; and (6) it had to have received an innovation or competitiveness award in the previous year. This last criterion was chosen as a benchmark for innovativeness, as it considers innovation both from the enterprise's as well as the market's perspective. We chose these criteria because they are representative of common small enterprises (Zaridis \& Mousiolis, 2014), and they are also consistent with Yin's (2017) and Eisenhardt's (1989) criteria for theoretical or analytical sampling, that is, they involve cases that are representative within a literature domain.

After obtaining the participants' consent, we conducted in-depth interviews with them using a semistructured interview script as a guiding tool (Appendix A). Each interview lasted about 120 minutes and was recorded and later transcribed. Additionally, we accessed data from social networks such as the Facebook and Instagram fan pages of the related businesses in order to better combine the interviewees' oral reports with the enterprises' digital personas, in a attempt at triangulation. This first stage of our field work was conducted between September and December of 2017. The names of the people interviewed and the businesses/cases were kept confidential. We conducted a pilot case with Case A in order to refine the interview script.

In a second stage, the transcribed raw data were organized and manually coded into tables and matrices as per Miles and Huberman's (1994) recommendations. This allowed for both an individual and a cross-case analysis of the forgotten businesses that composed our study, thus making it possible to search for similarities and differences between cases and then pursue a replication logic among them (Eisenhardt, 1989; Langley \& Abdallah, 2011). Categories and elements of analysis were derived from the interviews, "enfolding literature" and "reaching closure," as per Eisenhardt's recommendations. Table 1 presents the owners who participated in the research along with their respective businesses, and Table 2 synthesizes the results of the comparative analysis. 
Table 1

\section{Profile of the owners and businesses in each case study}

\begin{tabular}{|c|c|c|c|c|c|}
\hline & Case A & Case B & Case C & Case D & Case E \\
\hline Name of the Owner & Owner A & Owner B & Owner C & Owner D & Owners E1 \& E2 \\
\hline Age of the Owner & 31 years & 53 years & 59 years & 55 years & 53 years and 29 years \\
\hline Business area & Barbershop & Pastry maker & Bakery & Carpentry & Coffeehouse \\
\hline Business sector & Service & Commerce & Industry & Industry & Commerce \\
\hline Time in operation & Since 2015 & Since 2008 & Since 1998 & Since 1992 & Since 2014 \\
\hline \multirow{2}{*}{$\begin{array}{l}\text { Number of } \\
\text { employees }\end{array}$} & 07 employees, & 26 employees & 17 employees & 27 employees & 12 employees \\
\hline & High turnover & High turnover & Low turnover & Low turnover & Low turnover \\
\hline \multirow[t]{3}{*}{$\begin{array}{l}\text { Main products/ } \\
\text { services/processes }\end{array}$} & $\begin{array}{l}\text { Products: beard and } \\
\text { hair balms }\end{array}$ & $\begin{array}{l}\text { Products: pastries } \\
\text { and sugarcane juice }\end{array}$ & Products: bread & $\begin{array}{c}\text { Products: closets and } \\
\text { wardrobes }\end{array}$ & $\begin{array}{l}\text { Products: coffee, tea, } \\
\text { cakes, and sweets }\end{array}$ \\
\hline & $\begin{array}{l}\text { Services: haircuts and } \\
\text { bear trimming }\end{array}$ & Services: events & $\begin{array}{l}\text { Services: breakfast } \\
\text { and lunch }\end{array}$ & $\begin{array}{c}\text { Services: } \\
\text { maintenance. } \\
\text { Process: section, } \\
\text { bonding, machining, } \\
\text { assembly }\end{array}$ & Services: events \\
\hline & Process: "alignment" & Process: food making & $\begin{array}{l}\text { Process: bread } \\
\text { making and freezing }\end{array}$ & & Process: food making \\
\hline \multirow[t]{2}{*}{ Main customers } & Well-defined profile & Well-defined profile & Well-defined profile & Well-defined profile & Well-defined profile \\
\hline & $\begin{array}{l}\text { Local customers: } \\
\text { men and children }\end{array}$ & $\begin{array}{l}\text { Local customers and } \\
\text { tourists }\end{array}$ & $\begin{array}{l}\text { Local customers and } \\
\text { tourists }\end{array}$ & $\begin{array}{l}\text { Local customers and } \\
\text { tourists }\end{array}$ & Local customers \\
\hline \multirow[t]{2}{*}{ Main competitors } & $\begin{array}{l}\text { There is no } \\
\text { cooperation }\end{array}$ & $\begin{array}{l}\text { There is no } \\
\text { cooperation }\end{array}$ & $\begin{array}{l}\text { There is cooperation } \\
\text { with other bakeries }\end{array}$ & $\begin{array}{l}\text { There is cooperation } \\
\text { between carpentries }\end{array}$ & $\begin{array}{l}\text { There is no } \\
\text { cooperation }\end{array}$ \\
\hline & $\begin{array}{l}\text { Two other local } \\
\text { barbershops with a } \\
\text { similar concept }\end{array}$ & $\begin{array}{l}\text { Local snack bars and } \\
\text { restaurants }\end{array}$ & Local restaurants & Freelancers & Local cafeterias \\
\hline Main suppliers & $\begin{array}{l}\text { There is cooperation } \\
\text { Local supplier }\end{array}$ & $\begin{array}{l}\text { There is cooperation } \\
\text { Local supplier }\end{array}$ & $\begin{array}{l}\text { There is cooperation } \\
\text { Local supplier }\end{array}$ & $\begin{array}{l}\text { There is cooperation } \\
\text { Local supplier }\end{array}$ & $\begin{array}{l}\text { There is cooperation } \\
\text { Local supplier }\end{array}$ \\
\hline Main threats & $\begin{array}{l}\text { Employees. In this } \\
\text { trade they are volatile } \\
\text { and move from } \\
\text { one barbershop to } \\
\text { another }\end{array}$ & $\begin{array}{l}\text { Reduction in } \\
\text { the customers' } \\
\text { purchasing power } \\
\text { because of the crisis }\end{array}$ & $\begin{array}{l}\text { Reduction in } \\
\text { the customers' } \\
\text { purchasing power } \\
\text { because of the crisis }\end{array}$ & $\begin{array}{l}\text { Reduction in } \\
\text { the customers' } \\
\text { purchasing power } \\
\text { because of the crisis. } \\
\text { Freelancers and } \\
\text { "garage businesses" }\end{array}$ & $\begin{array}{l}\text { Reduction in } \\
\text { the customers' } \\
\text { purchasing power } \\
\text { because of the crisis }\end{array}$ \\
\hline Main innovations & $\begin{array}{l}\text { Pioneer in value } \\
\text { proposition; } \\
\text { "alignment of } \\
\text { haircuts;" new } \\
\text { haircuts and styles }\end{array}$ & $\begin{array}{l}\text { Pioneer in value } \\
\text { proposition; } \\
\text { redefining processes } \\
\text { and menu; event } \\
\text { services }\end{array}$ & $\begin{array}{l}\text { Pioneer in value } \\
\text { proposition; bread } \\
\text { freezing process; } \\
\text { event services }\end{array}$ & $\begin{array}{l}\text { Pioneer in value } \\
\text { proposition; } \\
\text { carpentry process } \\
\text { control; photo } \\
\text { engraving on wood }\end{array}$ & $\begin{array}{l}\text { Pioneer in value } \\
\text { proposition; } \\
\text { constantly redefining } \\
\text { the menu; event } \\
\text { services }\end{array}$ \\
\hline Major awards & $\begin{array}{c}\text { Banco do Nordeste's } \\
\text { Innovative Featured } \\
\text { Company (2016) }\end{array}$ & $\begin{array}{c}\text { SEBRAE's } \\
\text { Small Business } \\
\text { Competitiveness } \\
\text { Award (2014) }\end{array}$ & $\begin{array}{c}\text { SEBRAE's } \\
\text { Small Business } \\
\text { Competitiveness } \\
\text { Award (2015) }\end{array}$ & $\begin{array}{c}\text { Banco do Nordeste's } \\
\text { Innovative Featured } \\
\text { Company (2017) }\end{array}$ & $\begin{array}{c}\text { Banco do Nordeste's } \\
\text { Innovative Featured } \\
\text { Company (2017) }\end{array}$ \\
\hline
\end{tabular}

The multiple case study design was chosen due to its strength in identifying patterns across different cases, and thus allowed us to compare personal characteristics of the owners, enterprise characteristics, as well as will and ability to innovate.

\section{Multiple Case Study}

The businesses covered in this study belong to traditional, low-technology sectors that probably exist even in the smallest of towns. In our case study, however, the owners of the forgotten businesses offer products/services/processes that "go beyond" the business model offered by their competitors. In other words, regardless of age, segment, sector, and time in operation, these owners have a clear vision of their businesses and the opportunities they can explore, and they think ahead of their time. Additionally, they have a clear understanding of the influences of their employees, customers, competitors, and suppliers, and 
Table 2

\section{Comparative analysis}

\begin{tabular}{|c|c|c|c|c|c|}
\hline & Case A & Case B & Case C & Case D & Case E \\
\hline \multicolumn{6}{|c|}{ Personal characteristics } \\
\hline Educational level & High school & College & College & College & High school/College \\
\hline $\begin{array}{c}\text { Business } \\
\text { management } \\
\text { education }\end{array}$ & No & Yes & No & No & $\mathrm{No} / \mathrm{Yes}$ \\
\hline Previous experience & Since a child/hobby & Since a child/hobby & Since a child/hobby & Since a child/hobby & Since a child/hobby \\
\hline Motivation & Wants more & Wants more & Wants more & Wants more & Wants more \\
\hline Leadership & Leads the team & Leads the team & Leads the team & Leads the team & Leads the team \\
\hline Will to change & Change-oriented & Change-oriented & Change-oriented & Change-oriented & Change-oriented \\
\hline Well-being & Enterprise is his life & Enterprise is her life & Enterprise is her life & Enterprise is his life & $\begin{array}{c}\text { Enterprise is their } \\
\text { lives }\end{array}$ \\
\hline \multicolumn{6}{|c|}{ Enterprise characteristics } \\
\hline $\begin{array}{l}\text { Savings, plan, time } \\
\text { for innovation }\end{array}$ & No & No & No & No & No \\
\hline $\begin{array}{c}\text { Process } \\
\text { optimization }\end{array}$ & $\begin{array}{l}\text { Everything is } \\
\text { optimized }\end{array}$ & $\begin{array}{c}\text { Everything is } \\
\text { optimized }\end{array}$ & $\begin{array}{l}\text { Everything is } \\
\text { optimized }\end{array}$ & $\begin{array}{l}\text { Everything is } \\
\text { optimized }\end{array}$ & $\begin{array}{l}\text { Everything is } \\
\text { optimized }\end{array}$ \\
\hline $\begin{array}{l}\text { Culture of } \\
\text { innovation }\end{array}$ & Owner-centered & Owner-centered & Owner-centered & Owner-centered & Owner-centered \\
\hline $\begin{array}{l}\text { Institutional } \\
\text { support }\end{array}$ & SEBRAE, BNB & SEBRAE, BNB & SEBRAE, BNB & $\begin{array}{c}\text { SEBRAE, SESI, } \\
\text { BNB }\end{array}$ & $\begin{array}{c}\text { SEBRAE, SENAI, } \\
\text { BNB }\end{array}$ \\
\hline Cooperation & Only with suppliers & Only with suppliers & There is cooperation & There is cooperation & Only with suppliers \\
\hline Internal flexibility & Strong flexibility & Strong flexibility & Strong flexibility & Strong flexibility & Strong flexibility \\
\hline Training programs & Internal and external & Internal and external & Internal and external & Internal and external & Internal and external \\
\hline \multicolumn{6}{|c|}{$\begin{array}{l}\text { Will and ability } \\
\end{array}$} \\
\hline $\begin{array}{l}\text { Concept of } \\
\text { innovation }\end{array}$ & $\begin{array}{l}\text { "Do not settle, never } \\
\text { settle down" }\end{array}$ & $\begin{array}{l}\text { "Never stay the same, } \\
\text { try to surprise" }\end{array}$ & $\begin{array}{l}\text { "To update oneself, } \\
\text { to always be better" }\end{array}$ & $\begin{array}{l}\text { "To do something in } \\
\text { a different way" }\end{array}$ & $\begin{array}{c}\text { "To do what is good } \\
\text { for your and surprise } \\
\text { others" }\end{array}$ \\
\hline $\begin{array}{c}\text { Introduction or } \\
\text { improvement of } \\
\text { products, services, } \\
\text { processes }\end{array}$ & $\begin{array}{l}\text { Constant. Contact } \\
\text { with national fairs } \\
\text { and barbershops } \\
\text { from other states and } \\
\text { countries }\end{array}$ & $\begin{array}{l}\text { Constant. Contact } \\
\text { with national fairs }\end{array}$ & $\begin{array}{l}\text { Constant. Contact } \\
\text { with national fairs } \\
\text { and bakeries from } \\
\quad \text { other states }\end{array}$ & $\begin{array}{l}\text { Constant. Contact } \\
\text { with national fairs } \\
\text { and carpentries from } \\
\text { other states }\end{array}$ & $\begin{array}{l}\text { Constant. Contact } \\
\text { with fairs and } \\
\text { national and } \\
\text { international } \\
\text { coffeehouses }\end{array}$ \\
\hline $\begin{array}{c}\text { Difficulties in } \\
\text { introducing } \\
\text { or improving } \\
\text { products, services, } \\
\text { processes }\end{array}$ & Know-how Financial & Know-how Financial & Know-how Financial & Know-how Financial & Know-how \\
\hline $\begin{array}{l}\text { Changes resulting } \\
\text { from the } \\
\text { introduction or } \\
\text { improvement of } \\
\text { products, services, } \\
\text { processes }\end{array}$ & $\begin{array}{l}\text { Quality, market } \\
\text { dominance, growth }\end{array}$ & $\begin{array}{l}\text { Quality, market } \\
\text { dominance, growth }\end{array}$ & $\begin{array}{l}\text { Quality, market } \\
\text { dominance, growth }\end{array}$ & $\begin{array}{l}\text { Quality, market } \\
\text { dominance, growth }\end{array}$ & $\begin{array}{l}\text { Quality, market } \\
\text { dominance, growth }\end{array}$ \\
\hline $\begin{array}{l}\text { Changes still to } \\
\text { occur }\end{array}$ & $\begin{array}{l}\text { To enlarge the } \\
\text { barbershop and } \\
\text { invest in the } \\
\text { customer experience }\end{array}$ & $\begin{array}{l}\text { To enlarge the pastry } \\
\text { maker and invest } \\
\text { in the customer } \\
\text { experience }\end{array}$ & $\begin{array}{c}\text { To enlarge the bakery } \\
\text { and start exporting } \\
\text { bread }\end{array}$ & $\begin{array}{l}\text { To enlarge the } \\
\text { carpentry and } \\
\text { start working with } \\
\text { alternative materials }\end{array}$ & $\begin{array}{l}\text { To invest even more } \\
\text { in the customer } \\
\text { experience }\end{array}$ \\
\hline
\end{tabular}

they have an innovative mindset that influences their behavior both as owners and managers.

Case $\mathrm{A}$ is a barbershop that is unique in having brought back the old classic concept of a barbershop as a "manly" space, with "manly" stuff, beer, and paraphernalia. Looking at it from the outside, one could mistake it for a bar, but they offer regular haircuts. Interestingly, to circumvent the old beliefs held by local men that 
certain hair grooming techniques are "things for women," they have created their own "manly" techniques, which basically adapt women's hair-styling techniques to their male customers.

Case B is a traditional pastry maker that started as a small stand at a trade fair. Known by people and institutions (since 2008 it has been awarded the prize of "best pastry in town") alike, the owner was literally forced out of the fair by other tenants, who could not stand her insistence on trying to "professionalize" the messy trade fair. She opened her own restaurant in a touristic area and became a reference for gastronomy in the city.

Case $\mathrm{C}$ is a traditional bakery that has operated for more than 20 years as a family business, but underwent a strong modernization process when the new owner - a sister-in-law - took over the business. They have introduced new machinery and methodologies to standardize management, bread making, and bread processing, and they now use an innovative bread dough freezing process, as well as standardized caking and other products, thus mitigating costs and improving the general quality of the products.

Case $\mathrm{D}$ is a carpentry business that started by building traditional furniture, but stood out among other competitors as the only carpentry in town that used information technology and automation to design, cut, and shape wood and other materials to the nearest millimeter, thus enabling a perfect fit once the furniture is assembled. This has created a new value proposition for the business, which was previously dependent on manual skilled workers and very prone to human error.

Case $\mathrm{E}$ is a coffeehouse founded by a mother and daughter that emulates the famous Parisian cafés. It was the first in town to come up with this themed business model and environment. They serve full meals, tea, soft drinks, alcoholic beverages, and even a luxurious five o'clock tea. They have recently started to hire out the space for wedding ceremonies, thus entering the event management business.

\section{I Characteristics of the owner}

Educational level and training in business management were not decisive for innovation in the enterprises in this study. This goes against the literature on innovation in small businesses (Romero \& MartínezRomán, 2012), but provides indications that owners acquire managerial skills in other ways and in accordance with business needs. The owners' vision of the business and opportunities to be explored drives the pursuit of necessary skills and the direction of the business.

All of the forgotten businesses covered in this case study started as commercial exploitation of a hobby by their owners. This aptitude provides a foundation for understanding the business (Verhees \& Meulenberg, 2004) and is generally more important for the enterprise than formal business management training or education. Turning a hobby into a business is a common feature among entrepreneurs, whether they are young (Hulsink \& Koek, 2014), enthusiasts and inventors (Baron \& Tang, 2011; Smith A. W., Moghaddam, \& Lanivich, 2019), or simply love what they do (Alonso, 2011).

Owners also demonstrate a natural desire to change (Taneja et al., 2016). This natural and personal orientation directs the innovations in their businesses. Likewise, in all the enterprises we studied the owners performed the multiple roles of manager, entrepreneur, and businessman or businesswoman at the same time (Moraes et al., 2014; Plotnikova et al., 2016).

The antecedent Characteristics of the Owner portrays the owner's psyche, or beliefs, expectations, thoughts, emotions, knowledge, and world view. We identified four factors responsible for innovation in the small enterprises: (1) previous experience in the business; (2) strategic vision; (3) leadership; and (4) a change-oriented vision (See Table 3 for empirical evidence).

Previous experience in the business is defined as the owner having prior contact with the trade or business activity of his/her enterprise. In the cases we studied, such previous working experience derived from the economic exploration of a hobby in which the person excelled, leading them to understand and expand the potential of their own businesses. Strategic vision refers to the ability to identify which innovation opportunities will be explored as well as defining the directions the business will take. Leadership is defined as the owner's ability to mobilize his/her employees around common business goals. Additionally, we found that an innovative culture is dependent upon the owner, who takes all decisions and influences the business. A change-oriented vision refers to the owner's ability to review his/her own psyche and try "different things." A change-oriented vision is of the utmost importance, especially in times of economic crisis, insecurity, and scarce resources (Al-Dajani, Carter, Shaw, \& Marlow, 2015; Jennings, Jennings, \& Sharifian 2016). 
Table 3

\section{Empirical evidences from the multiple case study}

\begin{tabular}{|c|c|}
\hline \multicolumn{2}{|r|}{ Characteristics of the Owner } \\
\hline Factors & Empirical Evidence \\
\hline $\begin{array}{l}\text { Previous experience } \\
\text { in the business }\end{array}$ & $\begin{array}{l}\text { "The kitchen fascinates me, the smells, the seasonings.... And I am [used to] making my own pastries at home, every } \\
\text { Sunday! I fry a bowl of pastries for my nephews and friends, because people love pastries. [That is] my destiny! It has } \\
\text { taken over my life" (Owner B) }\end{array}$ \\
\hline Strategic vision & $\begin{array}{l}\text { "I saw that this old carpentry model was dead already. You cannot depend on the woodworker... I noticed that. I had } \\
\text { to do something. I had to modernize [my business]. My competitors did not have the courage, they thought it was a } \\
\text { very big leap" (Owner D) }\end{array}$ \\
\hline Leadership & $\begin{array}{l}\text { "I always say that I am a catalyst. What does the catalyst do? Without the catalyst the photosynthesis cannot happen... } \\
\text { I do a little bit of everything. I have those old [employees], and each of them perform their own roles" (Owner C) }\end{array}$ \\
\hline $\begin{array}{l}\text { Change-oriented } \\
\text { vision }\end{array}$ & $\begin{array}{l}\text { "When I get here I'm already feeling nervous... Many people say: 'This barbershop is beautiful!' or 'What is this } \\
\text { [object]!?'... But I'm already feeling saturated. When I innovate, when I put something new here, [it fills] my spirit... } \\
\text { It gives me much more energy. It feels like I always have the need to start over, you know?" (Owner A) }\end{array}$ \\
\hline \multicolumn{2}{|r|}{ Characteristics of the Enterprise } \\
\hline Factors & Empirical Evidence \\
\hline $\begin{array}{c}\text { Process } \\
\text { optimization }\end{array}$ & $\begin{array}{l}\text { "We could not map everything [in the bread making, cake baking, and other product processes], but we mapped } \\
\text { almost everything! It's a challenge! We are always trying to improve. It helps to standardize [the product] and also } \\
\text { offer something new. [...] With this [course] they are teaching us a methodology of bakery management. That makes } \\
\text { all the difference!" (Owner C) }\end{array}$ \\
\hline Internal flexibility & $\begin{array}{l}\text { "The first marriage ceremony was not our idea, the customer asked us to do it. The person said she was getting married } \\
\text { and wanted to have the party here. We had never done it before, so it was like 'Let's develop this idea together!'... } \\
\text { Then that was when we started creating the wedding format in the coffeehouse" (Owner E2) }\end{array}$ \\
\hline Training programs & $\begin{array}{l}\text { "There are suppliers of materials and machines who give us training courses paid by their own companies. They bring } \\
\text { a mini lab over here... And I paid for courses and events for the employees. We have an agreement with SESI. It is } \\
\text { important for me" (Owner D) }\end{array}$ \\
\hline $\begin{array}{l}\text { External } \\
\text { institutional } \\
\text { support }\end{array}$ & $\begin{array}{l}\text { "The trajectory of the business itself has to do with SEBRAE. I sought SEBRAE to get licenses, to know how to work } \\
\text { perfectly. I followed everything! I attended many courses there, financial management, entrepreneurship... I was a } \\
\text { 'quarrelsome' student and kept arguing with the teachers [laughs]" (Owner B) }\end{array}$ \\
\hline \multicolumn{2}{|r|}{ Will and Ability to Innovate } \\
\hline Factors & $\begin{array}{l}\text { Empirical Evidences } \\
\end{array}$ \\
\hline Resilience & $\begin{array}{l}\text { "Need made me seek an alternative. I saw a friend working at the fair and I decided to buy a pastry stall. I used R\$ } \\
20,000 \text { from my credit card, and it took me eight months to get it paid... But the people there did not understand that } \\
\text { if they took proper care of the fair things would improve. They did not want me there! But then I had the audacity to } \\
\text { start here [current headquarters] even without having the money. My house is here, } R \$ 700,000 \text { from my mortgage!" } \\
\text { (Owner B) }\end{array}$ \\
\hline $\begin{array}{l}\text { Personal up-to- } \\
\quad \text { dateness }\end{array}$ & $\begin{array}{l}\text { "I have always attended fairs, congresses... A turning point in our lives was a congress, a speech, some } 16 \text { years ago, a } \\
\text { course on baking with monthly modules... When it was over I was like crazy: 'I need to take this to my hometown!"” } \\
\text { (Owner C) }\end{array}$ \\
\hline Growth orientation & $\begin{array}{l}\text { "I really respect what each person wants for their own life. It's not that the person is not good, sometimes it's what } \\
\text { the person wants for his or her own life, it's what makes him or her feel happy, what he or she pictured for himself/ } \\
\text { herself... I pictured something else for myself. This business is the project of my life, it is [part of] my personality" } \\
\text { (Owner A) }\end{array}$ \\
\hline $\begin{array}{l}\text { Cosmopolitan } \\
\text { behavior }\end{array}$ & $\begin{array}{l}\text { "We did not have this concept of barbershop here in the city... It came from Sáo Paulo, it was a European trend. } \\
\text { And if you are a barber, you're always following the social networks of other barbers. And I was like: 'Look, the men's } \\
\text { salon is modernizing! Now it's going to have a more masculine footprint... It has beer, it has a pool table!'” (Owner A) }\end{array}$ \\
\hline
\end{tabular}

\subsection{Characteristics of the enterprise}

The owners in our cases do not spend time and money on innovations, nor do they have a structured innovation plan. Innovation occurs "on the go" as they come in contact with new products, services, or processes. In such forgotten businesses the trivial, day-to-day activities and routines blend with informal innovation activities, and it is natural that there is no such resource allocation (Forsman, 2011).

A culture of innovation and cooperation was not decisive for innovation in these businesses either. The owner does all of the decision making and is ultimately responsible for the innovation (Cooper et al., 2016; De Jong \& Marsili, 2006; Martínez-Román \& Romero, 2017; 
Verhees \& Meulenberg, 2004). Even though cooperation tends to lead to innovations, the lack of cooperation with competitors is offset by the owner's own innovative orientation.

Process optimization, institutional support, internal flexibility, and training programs may more adequately explain the innovation activities developed by these enterprises. Process optimization is a way of improving business performance and developing innovations. Internal flexibility allows the owners to take advantage of immediate opportunities. Training programs transform the owner's entrepreneurial ambitions into de facto actions, thus reengineering mindsets and behavior (Galende $\&$ de la Fuente, 2003; Glover et al., 2016).

The antecedent Characteristics of the Enterprise portrays what composes the physical environment, resources, and structure of the business itself, that is, the place where the owner's actions occur. We identified four innovation factors related to this antecedent: (1) process optimization; (2) internal flexibility; (3) training programs; and (4) external institutional support (See Table 3 for empirical evidence).

Process optimization involves the mapping of processes and the efficient use of resources. Since the innovation activities in small enterprises merge with their day-to-day activities, this factor allows the exploration of the business potential and the development of innovations. Internal flexibility refers to the adaptability and suitability of small enterprises in the face of new circumstances and demands, enabling better responsiveness and exploitation of immediate opportunities that may lead to innovations. The training programs factor involves the provision of training/development courses to the employees. It allows the alignment between the activities developed by the employees and the strategic vision of the owner. External institutional support is the presence of supporting agencies or government bodies, which represent an important form of assistance and collaboration for forgotten businesses, as noted elsewhere (Bradley, Hayter, \& Link, 2013; Santamaría et al., 2009).

\section{$5 \cdot 3$ Will and ability to innovate}

Owners tend to see innovation as part of themselves and the business (Carland et al., 2015), as a natural result of their personal history and the history of the business. The owners pursue innovations that go beyond those adopted by their business competitors. Their actions are based on their own world views, so they try to aggregate everything that is part of their creative imagination into their businesses. The trajectories of these businesses are intertwined and mixed up with the personal trajectories of their owners. All of the owners have faced critical events that made them rethink their own values as human beings as well as the values of their businesses, thus contributing to reshaping their enterprises as well as their understanding of the economic and social roles of their businesses.

The antecedent Will and Ability to Innovate portrays the actions and choices of the owner and is determined by the interaction between the antecedents "personal characteristics" and "enterprise characteristics." We identified four factors that explain this antecedent: (1) resilience; (2) personal up-to-dateness; (3) growth orientation; and (4) cosmopolitan behavior (See Table 3 for empirical evidence).

Resilience is the ability to adapt to an extremely adverse situation. It leads owners to react and seek innovative alternatives. The owners in our study showed remarkably resilient behavior throughout their personal and business trajectories. Personal up-to-dateness refers to seeking out courses and experiences that improve the performance of the business and the owner's innovative capabilities. It involves participation in fairs, events, and congresses and was identified as the main external source of innovation of the small businesses we studied. As all of the owners in our cases are oriented towards change, they seek easy solutions that enable their innovative aspirations. This tendency for reinvention and "self-updating" to overcome difficulties by accessing external sources of knowledge has grown substantially (Hayter, 2016).

Growth orientation refers to the owner's constant search for innovations and their sense of nonconformity. Cosmopolitan behavior is the adoption of innovations independent of and above the local standards. The growth parameter gauges the owner's willingness to see the business thrive regardless of the innovations or lack of innovations experienced in the market. This cosmopolitan business and life attitude has been found to be important in other studies (e.g. Hayter, 2016; Nikolopoulos \& Dana, 2016).

\section{Conclusion}

This research aimed to understand how small business owners develop innovations. The results explain what drives business owners to innovate and what affects the innovation structure of their businesses. These results are expressed by the antecedents of innovation that emerged from the field and may help explain the differences between innovative small businesses and non-innovative small businesses. 
The peculiarities of forgotten businesses and their involvement at the regional level require innovation models or approaches that are capable of capturing the context of innovation in these businesses. Small businesses are often singled out as being less innovative because of misunderstandings when analyzing their innovation results. The innovation outputs that make up an owner-centered innovation approach are appropriate for the innovation context of forgotten businesses and represent the innovative success of the businesses we studied.

In the Behavioral Model of Innovation, built based on Bandura's (1986) Social Cognitive Theory and Schumpeter's (1939) Theory of Economic Development, the antecedents of innovation are shaped by the interactions in the model. Therefore, it is possible to act on each antecedent to generate innovations. This allows us to identify what forgotten businesses need in order to innovate, and it lets us act upon the attributes that would make the small businesses innovative.

Small business innovation must be "thought of out of the box" of the usual innovation patterns. The peculiarities of forgotten businesses and their involvement at the regional level require models that are able to capture the context of innovation of these businesses. The Behavioral Model of Innovation has been developed for forgotten businesses. The innovation outputs of these enterprises are commonly disregarded by traditional innovation models because of the unit of analysis and the use of recursive theories. As a result, even small business supporting agencies or government bodies direct their efforts towards the structure and not the owner - the human behind the business. Supporting bodies, government, and researchers alike must question how the manager/owner's psychological barriers hinder business growth and act accordingly.

Our main limitation pertains to the methodological choice of using a case study research design which, because of its own nature, offers an in-depth understanding of the phenomenon, but cannot fully offer a statistical generalization. That being said, our findings are related to small businesses studied in a very specific context. Nevertheless, we build on Eisenhardt's (1989) and Yin's (2017) steps for conducting a theoretically sound case study.

In order to contribute to the development of innovations in forgotten businesses, we have listed a number of recommendations for supporting agencies, government bodies, and researchers alike. For supporting agencies and government bodies, we recommend the following: a) developing actions to support small businesses accompanied and/or preceded by actions directed towards the personal characteristics of small business owners; b) developing innovative actions focusing on the antecedents of innovation in small businesses; and c) exploring and encouraging the potential of localities through the abilities and "passions" of potential future entrepreneurs. For researchers, we recommend the following: a) considering the small business owner as the unit of analysis in their future research; b) investigating the role of forgotten businesses in the economic and social development of localities; c) adopting the forgotten business as an object of study; d) trying to replicate this study with polar cases - innovative and non-innovative forgotten businesses; and e) adopting an owner-centered approach to studying innovation in small businesses.

\section{References}

Aminu, I. M., \& Shariff, M. N. M. (2015). Determinants of SMEs performance in Nigeria: A pilot study. Mediterranean Journal of Social Sciences, 6(1), 156.

Antonioli, D., \& Della Torre, E. (2015). Innovation adoption and training activities in SMEs. The International Journal of Human Resource Management, 27(3), 311-337.

Al-Dajani, H., Carter, S., Shaw, E., \& Marlow, S. (2015). Entrepreneurship among the displaced and dispossessed: Exploring the limits of emancipatory entrepreneuring. British Journal of Management, 26(4), 713-730.

Alonso, A. D. (2011). Opportunities and challenges in the development of micro-brewing and beer tourism: A preliminary study from Alabama. Tourism Planning \& Development, 8(4), 415-431.

Avlonitis, G. J., Kouremenos, A., \& Tzokas, N. (1994). Assessing the innovativeness of organizations and its antecedents: Project innovstrat. European Journal of Marketing, 28(11), 5-28.

Bandura, A. (1986). Social foundations of thought and action: A social cognitive theory. New Jersey: Prentice Hall.

Baron, R. A., \& Tang, J. (2011). The role of entrepreneurs in firm-level innovation: Joint effects of positive affect, creativity, and environmental dynamism. Journal of Business Venturing, 26(1), 49-60. 
Barreto, J. C., Nassif, J., \& Maria, V. (2014). O empreendedor líder e a disseminação da orientação empreendedora. Revista Brasileira de Gestáo de Negócios, 16(51), 180-198.

Berends, H., Jelinek, M., Reymen, I., \& Stultiëns, R. (2014). Product innovation processes in small firms: Combining entrepreneurial effectuation and managerial causation. Journal of Product Innovation Management, 31(3), 616-635.

Birkinshaw, J., Hamel, G., \& Mol, M. J. (2008). Management innovation. Academy of Management Review, 33(4), 825-845.

Blanchard, K. (2017). Rural and remote SMEs' innovative behaviour: Is it in the genes or location? An examination of entrepreneurial traits and characteristics. Strategic Change, 26(4), 301-309.

Bradley, S. R., Hayter, C. S., \& Link, A. N. (2013). Proof of concept centers in the United States: An exploratory look. Journal of Technology Transfer, 38(4), 349-381.

Brinberg, D., \& McGrath, J. E. (1985). Validity and the research process. (3rd ed.) California: Sage Publications.

Brunswicker, S., \& Ehrenmann, F. (2013). Managing open innovation in SMEs: A good practice example of a German software firm. International Journal of Industrial Engineering and Management, 4(1), 33-41.

Carland, J. C., Carland, J. W., \& Stewart, W. H. (2015). Seeing what's not there: the enigma of entrepreneurship. Journal of Small Business Strategy, 7(1), 1-20.

Cooper, D., Peake, W., \& Watson, W. (2016). Seizing opportunities: The moderating role of managerial characteristics on the relationship between opportunityseeking and innovation efficacy in small businesses. Journal of Small Business Management, 54(4), 1038-1058.

Crossan, M. M., \& Apaydin, M. (2010). A multidimensional framework of organizational innovation: A systematic review of the literature. Journal of Management Studies, 47(6), 1154-1191.

Damanpour, F. (2014). Footnotes to research on management innovation. Organization Studies, 35(9), 1265-1285.
Daneji, A. A., Shavarebi, K., \& Yap, J. B. H. (2019). Owner-manager characteristics influence on the SMEs innovation orientation of SMEs: A literature exploration. International Journal, 1(2), 01-12.

Dansoh, A., Oteng, D., \& Frimpong, S. (2017). Innovation development and adoption in small construction firms in Ghana. Construction Innovation, 17(4), 511-535.

De Jong, J. P., \& Marsili, O. (2006). The fruit flies of innovations: A taxonomy of innovative small firms. Research Policy, 35(2), 213-229.

De Massis, A., Kotlar, J., Chua, J. H., \& Chrisman, J. J. (2014). Ability and willingness as sufficiency conditions for family-oriented particularistic behavior: Implications for theory and empirical studies. Journal of Small Business Management, 52(2), 344-364.

Dunne, T. C., Aaron, J. R., McDowell, W. C., Urban, D. J., \& Geho, P. R. (2016). The impact of leadership on small business innovativeness. Journal of Business Research, 69(11), 4876-4881.

Eisenhardt, K. M. (1989). Building theories from case study research. Academy of Management Review, 14(4), 532-550.

Farace, S., \& Mazzotta, F. (2015). The effect of human capital and networks on knowledge and innovation in SMEs. Journal of Innovation Economics Management, (1), 39-71.

Ferreira, J. J. M., Fernandes, C. I., Alves, H., \& Raposo, M. L. (2015). Drivers of innovation strategies: Testing the Tidd and Bessant (2009) model. Journal of Business Research, 68(7), 1395-1403.

Fitjar, R. D., Gjelsvik, M., \& Rodríguez-Pose, A. (2013). The combined impact of managerial and relational capabilities on innovation in firms. Entrepreneurship and Regional Development, 25(5-6), 500-520.

Forsman, H. (2011). Innovation capacity and innovation development in small enterprises: A comparison between the manufacturing and service sectors. Research Policy, 40(5), 739-750.

Freel, M. S. (2005). Patterns of innovation and skills in small firms. Technovation, 25(2), 123-134. 
Galende, J., \& de la Fuente, J. M. de (2003). Internal factors determining a firm's innovative behaviour. Research Policy, 32(5), 715-736.

Garcia, R., \& Calantone, R. (2002). A critical look at technological innovation typology and innovativeness terminology: A literature review. Journal of Product Innovation Management, 19(2), 110-132.

Gioia, D. A., \& Sims, H. P. Jr. (1986). Cognition-behavior connections: Attribution and verbal behavior in leadersubordinate interactions. Organizational Behavior and Human Decision Processes, 37(2), 197-229.

Glover, J., Champion, D., Daniels, K., \& Boocock, G. (2016). Using capital theory to explore problem solving and innovation in small firms. Journal of Small Business and Enterprise Development, 23(1), 25-43.

Hayter, C. S. (2016). Constraining entrepreneurial development: A knowledge-based view of social networks among academic entrepreneurs. Research Policy, 45(2), 475-490.

Higgins E. T. (2000). Social cognition: Learning about what matters in the social world. Eur,opean Journal of Social Psychology, 30(1), 3-39.

Hotho, S., \& Champion, K. (2011). Small businesses in the new creative industries: Innovation as a people management challenge. Management Decision, 49(1), 29-54.

Hosseini, M. P., \& Narayanan, S. (2014). Adoption, adaptive innovation, and creative innovation among SMEs in Malaysian manufacturing. Asian Economic Papers, 13(2), 32-58.

Huarng, K.-H., \& Ribeiro-Soriano, D. E. (2014). Developmental management: Theories, methods, and applications in entrepreneurship, innovation, and sensemaking. Journal of Business Research, 67(5), 657-662.

Hulsink, W., \& Koek, D. (2014). The young, the fast and the furious: A study about the triggers and impediments of youth entrepreneurship. International Journal of Entrepreneurship and Innovation Management, 18(2-3), 182-209.

Ilouga, S. N., Mouloungni, A. C. N., \& Sahut, J- M. (2014). Entrepreneurial intention and career choices: The role of volition. Small Business Economics, 42(4), 717-728.
Jennings, J. E., Jennings, P. D., \& Sharifian, M. (2016). Living the dream? Assessing the "entrepreneurship as emancipation" perspective in a developed region. Entrepreneurship Theory and Practice, 40(1), 81-110.

Kraaijenbrink, J., Spender, J.- C., \& Groen, A. J. (2010). The resource-based view: A review and assessment of its critiques. Journal of Management, 36(1), 349-372.

Langley, A., \& Abdallah, C. (2011). Templates and turns in qualitative studies of strategy and management. Research Methodology in Strategy and Management, 6, 201-235.

Lawson, B., \& Samson, D. (2001). Developing innovation capability in organisations: A dynamic capabilities approach. International Journal of Innovation Management, 5(03), 377-400.

Liñán, F., Santos, F. J., \& Fernández, J. (2011). The influence of perceptions on potential entrepreneurs. International Entrepreneurship and Management Journal, 7(3), 373.

Magadley, W., \& Birdi, K. (2012). Two sides of the innovation coin? An empirical investigation of the relative correlates of idea generation and idea implementation. International Journal of Innovation Management, 16(01).

Martínez-Román, J. A., \& Romero, I. (2017). Determinants of innovativeness in SMEs: Disentangling core innovation and technology adoption capabilities. Review of Managerial Science, 11(3), 543-569.

McGuirk, H., Lenihan, H., \& Hart, M. (2015). Measuring the impact of innovative human capital on small firms' propensity to innovate. Research Policy, 44(4), 965-976.

Miles, M. B., \& Huberman, A. M. (1994). Qualitative data analysis: An expanded sourcebook. USA: SAGE Publications.

Moraes, C., Philippsen, L. Jr., Lirani, H., Yamanaka, L., Rosim, D., \& Escrivão, E. Fº (2014). Systematic mapping study in small business: the quest for contemporary understanding. Procedia-Social and Behavioral Sciences, 143, 916-920.

Nikolopoulos, K.-P., \& Dana, L.-P.(2016). Toward a framework for studying cosmopolitanism, entrepreneurship and society. International Journal of Entrepreneurship and Small Business, 28(4), 414-430. 
Olughor, R. J. (2015). Effect of innovation on the performance of SMEs organizations in Nigeria. Management, 5(3), 90-95.

Patanakul, P., \& Pinto, J. K. (2014). Examining the roles of government policy on innovation. The Journal of High Technology Management Research, 25(2), 97-107.

Plotnikova, M., Romero, I., \& Martínez-Román, J. A. (2016). Process innovation in small businesses: The selfemployed as entrepreneurs. Small Business Economics, 47(4), 939-954.

Read, A. (2000). Determinants of successful organisational innovation: A review of current research. Journal of Management Practice, 3(1), 95-119.

Romero, I., \& Martínez-Román, J. A. (2012). Selfemployment and innovation. Exploring the determinants of innovative behavior in small businesses. Research Policy, 41(1), 178-189.

Rothwell, R. (1989). Small firms, innovation and industrial change. Small Business Economics, 1(1), 51-64.

Santamaría, L., Nieto, M. J., \& Barge-Gil, A. (2009). Beyond formal R\&D: Taking advantage of other sources of innovation in low-and medium-technology industries. Research Policy, 38(3), 507-517.

Schumpeter, J. A. (1939). Business cycles: A theoretical, historical and statistical analysis of the capitalist process (vol. 1). New York: McGraw-Hill.

Silva, G., Dacorso, A. L. R., \& Montenegro, L. M. (2016). Mais do que negócios abertos, mentes abertas. Revista de Empreendedorismo e Gestäo de Pequenas Empresas, 5(2), 3-23.

Smith, M., Busi, M., Ball, P., \& Van Der Meer, R. (2008). Factors influencing an organisation's ability to manage innovation: A structured literature review and conceptual model. International Journal of Innovation Management, 12(04), 655-676.

Smith, A. W., Moghaddam, K., \& Lanivich, S. E. (2019). A set-theoretic investigation into the origins of creation and discovery opportunities. Strategic Entrepreneurship Journal, 13(1), 75-92.
Storey, D. J. (2014). Understanding the small business sector: reflections and confessions. In P. Braunerhjelm (Ed.), 20 years of Entrepreneurship Research,: from small dynamics to entrepreneural growth and societal prosperity (Cap. 2, pp. 21-31). Swedish Entrepreneurship Forum. Retrieved from: https:/entreprenorskapsforum.se/wpcontent/uploads/2014/03/20_years_of_e-ship_web.pdf

Taneja, S., Pryor, M. G., \& Hayek, M. (2016). Leaping innovation barriers to small business longevity. Journal of Business Strategy, 37(3), 44-51.

Tang, H. K. (1998). An integrative model of innovation in organizations. Technovation, 18(5), 297-309.

Ucbasaran, D., Westhead, P., \& Wright, M. (2008). Opportunity identification and pursuit: Does an entrepreneur's human capital matter?. Small Business Economics, 30(2), 153-173.

Uzkurt, C., Kumar, R., Kimzan, H. S., \& Eminoglu, G. (2013). Role of innovation in the relationship between organizational culture and firm performance: A study of the banking sector in Turkey. European Journal of innovation management, 16(1), 92-117.

Van de Panne, G., Van Beers, C., \& Kleinknecht, A. (2003). Success and failure of innovation: A literature review. International Journal of Innovation Management, 7(3), 309-338.

Verhees, F. J. H. M., \& Meulenberg, M. T. (2004). Market orientation, innovativeness, product innovation, \& performance in small firms. Journal of Small Business Management, 42(2), 134-154.

Whittaker, D. H., Fath, B. P., \& Fiedler, A. (2016). Assembling capabilities for innovation: evidence from New Zealand SMEs. International Small Business Journal, 34(1), 123-143.

Yin, R. K. (2017). Case Study Research and Applications: Design and Methods. United States: Sage Publications.

Zaridis, A. D., \& Mousiolis, D. T. (2014). Entrepreneurship and SME's organizational structure: Elements of a successful business. Procedia-Social and Behavioral Sciences, 148, 463-467. 


\section{Appendix A [[Q1: Q1]]}

Interview Script

Observation: All interviews should be recorded with the consent of the interviewees and later transcribed in order to facilitate the analysis of the evidence. Interviewees: managers / owners.

\section{Manager/owner and company presentation}

1. Name of manager / owner;

2. Age of manager / owner;

3. Segment of the company;

4. Sector of activity;

5. Age of the company;

6. Number of employees;

7. Main products / services / processes;

8. Major customers;

9. Main competitors;

10. Major suppliers;

11. Major threats;

12. Major innovations;

13. Major awards.

\section{Personal characteristics}

1. Educational level;

2. Business management training;

3. Experience in the business area;

4. Personal trajectory and life history;

5. Motivation to open the business;

6. Leadership style;

7. Vision for change;

8. Meaning of business to the manager / owner;

9. Personal characteristics that help in the business;

10. Personal characteristics that limit the business.

\section{Business characteristics}

1. Story of opening the business;

2. Reserve money for innovation;

3. Time dedicated to innovation;

4. Innovation plan;

5. Process optimization;

6. Culture of innovation;

7. Institutional support;

8. Cooperation;

9. Internal flexibility;

10. Training programs.

\section{Will and skill}

1. Concept of innovation;

2. Innovation activities carried out in the company;

3. Introduction / improvement of products / services / processes since the opening of the company;

4. Difficulties in introducing / improving these products / services / processes;

5. Changes resulting from the introduction / improvement of these products / services / processes;

6. What innovation represents to the manager;

7. What the company can still accomplish;

8. Difficulties for future changes. 


\section{Financial support:}

Coordenação de Aperfeiçoamento de Pessoal de Nível Superior - CAPES.

\section{Conflicts of interest:}

The authors have no conflict of interest to declare.

\section{Copyrights:}

RBGN owns the copyrights of this published content.

\section{Plagiarism analysis:}

RBGN performs plagiarism analysis on all its articles at the time of submission and after approval of the manuscript using the iThenticate tool.

\section{Authors:}

1. Glessia Silva, Post Doctorate in Administration of Business, Fundação Getulio Vargas, São Paulo, Brazil. glessiasilva@hotmail.com

2. Luiz Carlos Di Serio, Post Doctorate in Administration, Aston University, Aston, England.

luiz.diserio@fgv.br

\section{Authors' Contributions:}

$\mathbf{1}^{\text {st }}$ author: definition of research problem; development of hypotheses or research questions (empirical studies); definition of methodological procedures; data collection; literature review; analysis and interpretation of data; critical revision of the manuscript; manuscript writing.

$2^{\text {nd }}$ author: definition of research problem; development of hypotheses or research questions (empirical studies); definition of methodological procedures; literature review; critical revision of the manuscript. 